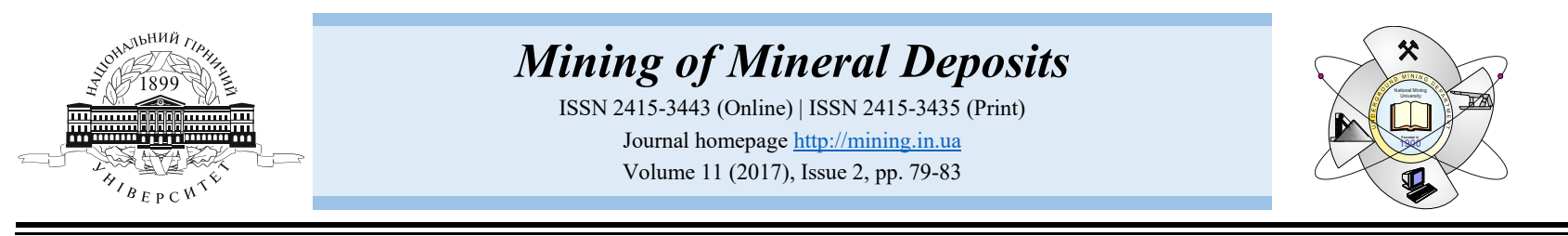

UDC 622.287

https://doi.org/10.15407/mining11.02.079

\title{
DISTANT INTERACTION OF ROCK MASS CLUSTERS AROUND UNDERGROUND OPENING
}

\author{
V. Griniov ${ }^{1}$, L. Zakharova ${ }^{2 *}$, I. Diedich ${ }^{3}$, V. Nazymko ${ }^{1}$ \\ ${ }^{I}$ Institute for Physics of Mining Processes of the National Academy of Sciences of Ukraine, Dnipro, Ukraine \\ ${ }^{2}$ Geodesy Department, Donetsk National Technical University, Pokrovsk, Ukraine \\ ${ }^{3}$ MA "Pokrovske", Pokrovsk, Ukraine \\ ${ }^{*}$ Corresponding author: e-mail zaharova mila1976@mail.ru, tel.+380504724729
}

\section{ДАЛЬНЯ ВЗАСМОДІЯ ПОРОДНИХ КЛАСТЕРІВ НАВКОЛО ПІДЗЕМНОЇ ВИРОБКИ}

\author{
В. Гріньов ${ }^{1}$, Л. Захарова ${ }^{2 *}$, І. Дєдіч ${ }^{3}$, В. Назимко ${ }^{1}$ \\ ${ }^{1}$ Інститут фізики гірничих прочесів НАН України, Дніпро, Україна \\ ${ }^{2}$ Кафедра геодезії, Донецький начіональний технічний університет, Покровськ, Украӥна \\ ${ }^{3} Ш У$ “Покровське”, Покровськ, Україна \\ *Biдповідальний автор: e-mail zaharova mila1976@mail.ru, тел. +380504724729
}

\begin{abstract}
Purpose. To experimentally prove the fact of distant interaction between rock clusters during the irreversible displacements of rock mass. Disintegration of the rock mass does not necessarily imply loss in underground working stability.

Methods. Telltales were used to monitor rock mass around the underground development working in conditions of intensive rock pressure manifestation.

Findings. This experiment has demonstrated that the boundary of the rock mass failure expands asynchronously by spatially and temporally discrete increments. Such mechanism of the rock failure zone development is the consequence of the minimum entropy production principle according to which dissipative structures can occur in open thermodynamic systems.
\end{abstract}

Originality. Distant interaction of rock clusters has been experimentally detected for the first time, which is important for geomechanics because it reveals the mechanism of the rock mass self-organization.

Practical implications. The most efficient special technologies have been selected and quantitatively assessed for the control of rock mass state in conditions of severe rock pressure manifestation.

Keywords: rock pressure, working stability, irreversible deformations, cluster, distant interaction

\section{INTRODUCTION}

Stability of underground openings, roadways, and entries deteriorates because of permanently increasing depth of mining. Maintenance of underground workings is a complex and urgent problem (Šn̆upárek \& Konečný, 2010; Meng et al., 2015). That is why a great number of technologies have been developed to provide stability of workings (Kang, 2014; Stahlmann, Missal, Huhn, \& Edel, 2014). However, efficiency of these technologies remains undervalued (Meng et al., 2015) because of insufficient knowledge concerning complex behavior of rock mass around underground openings.

Disintegration of rock mass does not imply loss of underground working stability. The rock mass may create a self-supporting effect (Nazimko, Lapteev, \& Sash- nev, 1997; Khomenko, Kononenko, \& Netecha, 2016). This positive synergetic effect occurs as the rock mass transits to a self-organizing state which creates selfsupportive structures in the sediment rocks. Such complex behavior of the rock mass has been studied in static so far (Yang et al., 2017; Xue, Gao, Liu, \& Liang, 2017). Evolution of the disintegration process is complex and has not been studied properly before. This paper describes the results of the research into the dynamics and kinematics of the disintegrated zone around the underground working on the basis of the theory of thermodynamics and instrumental observations in a coal mine.

Experiments have been conducted at a coal mine with subsequent computer simulation of the underground working reaction to severe ground pressure impact. 


\section{IN-SITU EXPERIMENT}

Monitoring of the disintegrating zone in the rock mass surrounding the main roadway has been conducted in "Pokrovska" coal mine at the depth of $845 \mathrm{~m}$. The main roadway was driven in $\mathrm{d}_{4}$ coal seam by road-header CSP43. The cross section of the roadway was $20.3 \mathrm{~m}^{2}$. It was supported with steel adjustable frames KSPUm standing at $0.8 \mathrm{~m}$ from each other. The roof of the roadway was reinforced by two $5 \mathrm{~m}$ long resin-grouted bolts and five $2.9 \mathrm{~m}$ long rope bolts. The rate of the roadway advance was $7 \mathrm{~m}$ per day.

The roof of the roadway was composed of shale with unconfined compressive stress $45 \mathrm{MPa}$, while the strength of the floor rock was $40 \mathrm{MPa}$. The detected water seepage from the roadway roof softened the rock and increased the problem of the roadway support.

Gaps between rock exposure and steel frames were filled with bull flexes or flexible bags filled with cement and sand mixture plus additives for quick solidification.

Experimental site was equipped between frames No. 1430 and No. 1429 where three holes were drilled, one into the roof and the other two into the sides of the roadway (Fig. 1). 14 telltales were installed into these holes. The depth of their installation in the roof hole was: $0.5 \mathrm{~m}, 1.8 \mathrm{~m}, 2.3 \mathrm{~m}, 3.2 \mathrm{~m}, 4.0 \mathrm{~m}, 5.2 \mathrm{~m}$, and $6.5 \mathrm{~m}$; in the left side hole: $1.9 \mathrm{~m}, 2.9 \mathrm{~m}$, and $3.8 \mathrm{~m}$; and in the right side hole: $1.0 \mathrm{~m}, 2.5 \mathrm{~m}$, and $3.9 \mathrm{~m}$.

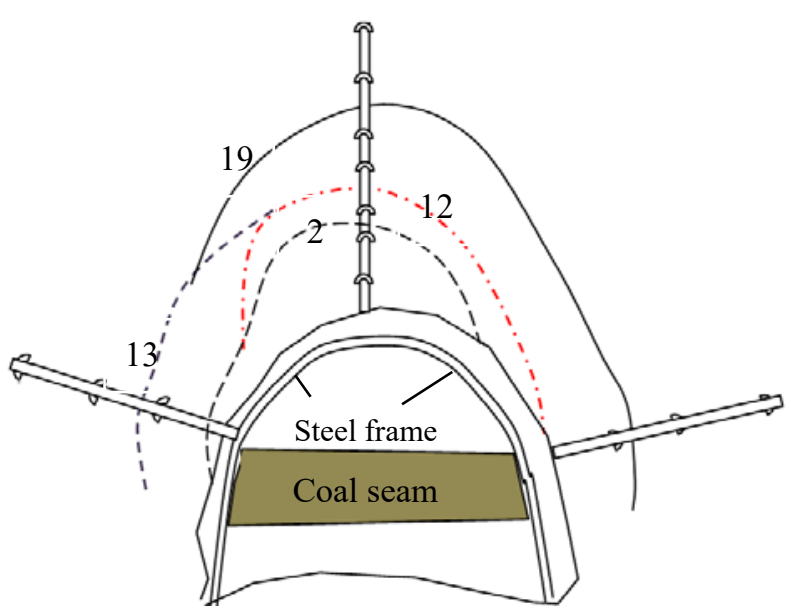

Figure 1. Layout of the experimental site

The monitoring process continued for 20 days after the roadway drivage or for 19 days after installation of the telltales. The roof rock lamination increased up to $300 \mathrm{~mm}$ at the end of the experiment, whereas the strata subsidence decreased as the distance from the roadway cavity increased (Fig. 2).

The bulfflexes prevented dilation of the immediate roof to the depth of $1,8 \mathrm{~m}$, but deeper layers got spalled which can be seen from the diagram in Figure 3. The maximum dilation of the roof rocks increased from 0.116 to 0.125 within the hole interval of $1.8 \mathrm{~m}$ to $2.4 \mathrm{~m}$. Meanwhile the interval of the hole from $2.4 \mathrm{~m}$ to $3.2 \mathrm{~m}$ increased its length from 1.056 to 1.074 times.

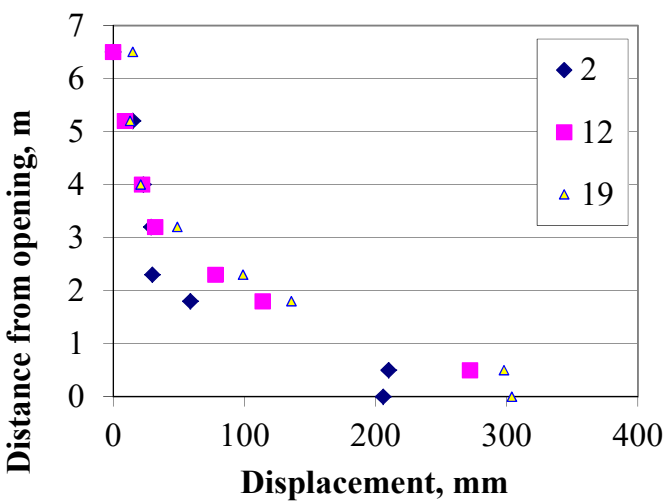

Figure 2. Displacements of telltales during the experiment

Testing of the shale in laboratory has demonstrated that the ultimate tensile strength for this rock was 0.015 . This level is marked by the dotted vertical line in the diagram of Figure 3. Comparing the actual dilation of the strata with the tension limit, we managed to reconstruct the kinematics of the disintegrated zone development in space and time. The surrounding rock mass has disintegrated and transited to over-peak state to the depth of $2 \mathrm{~m}$ in the roof and $0.4 \mathrm{~m}$ in the left side of the roadway 2 days after telltales installation or 3 days after roadway drivage.

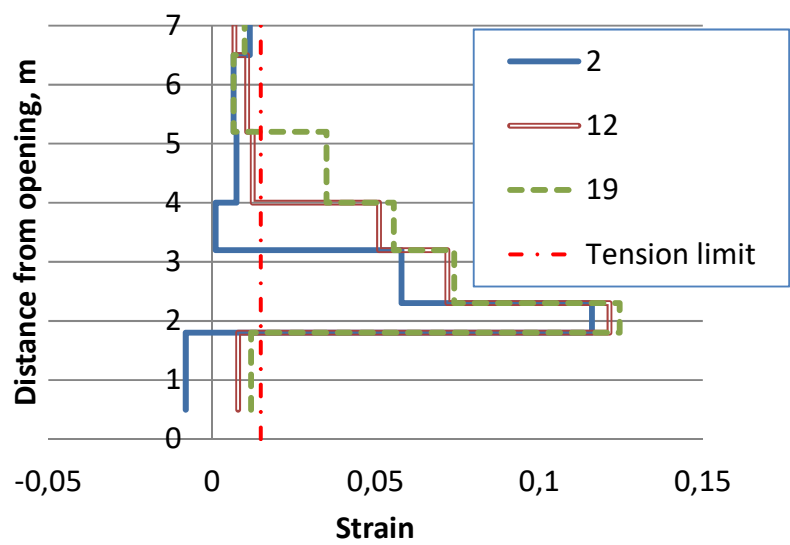

Figure 3. Strata strain evolution

Twelve days later, the disintegrated zone expanded to $3.6 \mathrm{~m}$ into the roof, and the next day (on the 13-th day after installation of the telltales), to $3 \mathrm{~m}$ into the left side of the roadway. The next expansion of the fragmented zone occurred to $4.8 \mathrm{~m}$ into the roof and to $2.0 \mathrm{~m}$ into the right side of the roadway 19 days later.

Eventually, the boundary of the disintegrated zone moved at least four times in the surrounding rock mass. Noticeably, this movement was accompanied by abrupt discrete leaps of the boundary in space and in time. The actual number of the leaps could be more, because the recorder might have missed the moments when the zone shifted its position.

Therefore, this experiment proved that the rock mass disintegrates around the underground opening and expands in space and time by discrete steps, which may be explained by the theory of thermodynamics (Kondepudi \& Prigogin, 2015). The rock mass in the vicinity of the underground working is an open thermodynamic system which transmits potential energy of rock pressure and 
dissipates it in the form of the surface energy of fractures and heat. As the experiment indicated, expansion of the disintegrated zone was intensive. Therefore, this irreversible thermodynamic process was non-stationary and could create dissipative structures as Kondepudi and Prigogin (2015) proved.

According to Haken (1981), the dissipative structures should occur due to interaction among thermodynamic components of the system. Nazimko and Zakharova (2010) pointed out that the typical thermodynamic components of the disintegrated rock mass are its clusters, which are the groups of the rock fragments that move consistently as a whole body, coordinating their movement in the zone.

The clusters create specific patterns such as vortexes, flows, diverging and converging fluxes. These patterns play an important role in minimizing the entropy production, which promotes self-organizing movement of the mass.

It means that the disintegrated zone could not expand smoothly, uniformly, and consistently in time and space. Separate clusters of the rock mass moved in turn giving way to each other. First, the cluster that was adjacent to the boundary 2 and the rock exposure moved into the roadway cavity and separated from the surrounding rock mass. Then the cluster situated between boundary 2 and 12 relocated, and so forth.

Uniform expansion of the disintegrated zone does not comply with the minimization of the entropy production. Such behavior demands much more energy to dissipate, which is hardly likely.

\section{DISCUSSION}

Researchers usually consider displacements of rock mass in the roof, sides, and floor of a roadway as practically independent processes. However, as the experiment demonstrated, the roof and sides coordinate their disintegration and movement. It is very probable, that the roof/sides/floor interaction would have been detected if the telltales had been installed in the floor. That is why we called interaction of the roof and sides the distant interaction. The distance between clusters in the roof and sides of the roadway approached $10 \mathrm{~m}$. Furthermore, the rock clusters in the roof and the floor are spaced by $20 \mathrm{~m}$ and even more, which exceeds cluster dimensions by an order.

The specific patterns of dissipative structures in the process of irreversible mass movement testify to their practical importance. Stepwise expansion of the disintegrated zone by small local portions (clusters) dissipates minimum amount of the rock pressure energy. Therefore, this process should be extended in time to dissipate enough energy to allow the process of rock displacement to attenuate. Such condition may result in accumulation of the great convergence on the underground working boundary, which may interfere with its proper functioning.

To reduce the convergence, we should change the mass behavior so that the clusters' movement is synchronized. The computer simulation showed that such mode of the mass movement takes $1.3-2.0$ times more rock pressure energy for the same mass displacement. The experiment demonstrated that the time interval between subsequent cluster movements increases in time. That is why the rate of the convergence decays as ground subsidence increases. Therefore, shifting mass behavior from stepwise cluster movement to synchronous displacement forces the convergence to attenuate. As a result, approximately the same amount of the rock pressure energy will be spent to produce less convergence.

Special investigations helped to select the relevant technologies that can synchronize the clusters' irreversible displacements (Table 1). Reinforcement with steel frames and rock bolts which work independently was selected as a benchmark technology for comparison. As it can be seen, spraying of cement mixtures on rock exposure reduces convergence of the roof by $11.6 \%$. The struts installed between rock bolt heads and then pretensioned are more efficient. This measure reduced rock displacements by $18.5 \%$.

\begin{tabular}{|c|c|c|c|}
\hline No. & Technology & $\begin{array}{l}\text { Displacenet of } \\
\text { the roadway } \\
\text { contour, mm }\end{array}$ & $\begin{array}{l}\text { Level, } \\
\%\end{array}$ \\
\hline 1 & $\begin{array}{l}\text { Steel frames plus rock bolts } \\
\text { which work independently }\end{array}$ & 362 & 100.0 \\
\hline 2 & $\begin{array}{l}\text { Spraying of cement } \\
\text { mixtures }\end{array}$ & 320 & 88.4 \\
\hline 3 & $\begin{array}{l}\text { Struts installed between } \\
\text { rock bolt heads }\end{array}$ & 295 & 81.5 \\
\hline 4 & $\begin{array}{l}\text { Combination of steel arches } \\
\text { and rock bolts or cables } \\
\text { working together }\end{array}$ & 235 & 64.9 \\
\hline 5 & $\begin{array}{l}\text { Rock bolts connected } \\
\text { to props }\end{array}$ & 224 & 61.9 \\
\hline 6 & Special rock bolts & 204 & 56.4 \\
\hline 7 & Pre-stressed cables & 110 & 30.4 \\
\hline 8 & $\begin{array}{l}\text { Injection of cement and } \\
\text { resin mixtures into the } \\
\text { rock mass }\end{array}$ & 95 & 26.2 \\
\hline
\end{tabular}

Combination of steel arches and rock bolts or cables working together may decrease roof displacement to $64.9 \%$ because the rock bolts resist tension and steel frames apply pressure to the roof of the roadway. Such combination of impacts provides an additional positive effect when the bolts are connected with the frames.

An innovative support has been proposed in the form of rock bolts connected to props. This combination works similar to the previous support system and ensures further improvement of the roadway.

Special rock bolts technologies encompass different options. For example, inclination of bolts in different directions creates a three-dimensional effect that provides extra reinforcement of the disintegrated rock mass. This technology may reduce rock displacement up to two times depending on the parameters. Such positive effect is produced if the inclination of the rock bolts is combined with technology No. 4.

The most efficient technologies are based on pretensioned cable bolts and injection of cement and polymer resins into disintegrated rock mass. Both technologies fix the clusters and prevent their stepwise movement. These technologies have an essential advantage such as selectivity and minimal labor intensity. In addition, they can be easily mechanized. 


\section{CONCLUSION}

Evolution of the disintegrated rock mass has been studied by monitoring irreversible mass movement around the underground opening. The rock mass disintegrates around the opening and expands in space and time by discrete steps. The boundary of the disintegrated zone moved at least four times in the surrounding rock mass and this movement followed as discrete abrupt leaps in space and time. Therefore, the rock mass disintegrated by discrete portions, one after another.

Development of the disintegrated zone is governed by thermodynamic law because the rock mass is an open thermodynamic system that creates dissipative structures. These structures are the consequence of the rock clusters' interaction. Uniform expansion of the disintegrated zone does not comply with minimization of entropy production. Such behavior demands much more energy to dissipate and its probability is negligible.

The most efficient technologies which can prevent the appearance of negative dissipative structures are pretensioned cable bolts and injection of cement and polymer resins into disintegrated rock mass. Both technologies fix the clusters and preclude their stepwise movement.

\section{ACKNOWLEDGEMENTS}

This research has been supported by the National Academy of Sciences of Ukraine (grant III-2-2017).

\section{REFERENCES}

Haken, H. (1981) The Science of Structure: Synergetics. New York: Van Nostrand Reinhold.

Kang, H. (2014). Support Technologies for Deep and Complex Roadways in Underground Coal Mines: A Review. International Journal of Coal Science \& Technology, 1(3), 261-277. https://doi.org/10.1007/s40789-014-0043-0

Khomenko, O., Kononenko, M., \& Netecha, M. (2016). Industrial Research into Massif Zonal Fragmentation around Mine Workings. Mining of Mineral Deposits, 10(1), 50-56. https://doi.org/10.15407/mining10.01.050
Kondepudi, D, \& Prigogin, I. (2015) Modern Thermodynamics: from Heat Engines to Dissipative Structures. England: John Wiley \& Song Ltd.

Meng, Q., Han, L., Sun, J., Min, F., Feng, W., \& Zhou, X. (2015). Experimental Study on the Bolt-Cable Combined Supporting Technology for the Extraction Roadways in Weakly Cemented Strata. International Journal of Mining Science and Technology, 25(1), 113-119. https://doi.org/10.1016/j.ijmst.2014.11.010

Nazimko, I.V., \& Zakharova, L.M. (2010) Clustering of the Ground Movement using Photogrammetric Methods. In Surveying in Geotechnologies (pp. 46-52). Dnipropetrovsk: Natsionalnyi hirnychyi universytet.

Nazimko, V.V., Lapteev, A.A., \& Sazhnev, V.P. (1997) Rock Mass Self-Supporting Effect Utilization for Enhancement Stability of a Tunnel. International Journal of Rock Mechanics and Mining Sciences, 34 (3-4), 657-657. https://doi.org/10.1016/s0148-9062(97)00222-2

Šňupárek, R., \& Konečný, P. (2010). Stability of Roadways in Coalmines Alias Rock Mechanics in Practice. Journal of Rock Mechanics and Geotechnical Engineering, 2(3), 281-288.

https://doi.org/10.3724/sp.j.1235.2010.00281

Stahlmann, J., Missal, C., Hahn, P., \& Edel, T. (2014). Geotechnical Conditions at the Konrad Mine - Excavation of Drifts and Rooms in Squeezing Rock / Geotechnische Bedingungen in der Schachtanlage Konrad - Auffahrung von Strecken und Kammern in Druckhaftem Gebirge. Mining Report, 150(5), 277-288. https://doi.org/10.1002/mire.201400029

Yang, R., Li, Y., Guo, D., Yao, L., Yang, T., \& Li, T. (2017). Failure Mechanism and Control Technology of Waterimmersed Roadway in High-stress and Soft Rock in a Deep Mine. International Journal of Mining Science and Technology, 27(2), 245-252. https://doi.org/10.1016/j.ijmst.2017.01.010

Xue, Y., Gao, F., Liu, X., \& Liang, X. (2017). Permeability and Pressure Distribution Characteristics of the Roadway Surrounding Rock in the Damaged Zone of an Excavation. International Journal of Mining Science and Technology, 27(2), 211-219.

https://doi.org/10.1016/j.ijmst.2017.01.003

\section{ABSTRACT (IN UKRAINIAN)}

Мета. Експериментально довести наявність дальньої взаємодії породних кластерів під час необоротних зрушень масиву гірських порід. Дезінтеграція масиву гірських порід не обов'язково тягне за собою втрату стійкості підземної виробки.

Методика. Використовуючи глибинні репери, здійснено моніторинг масиву гірських порід навколо підземної підготовчої виробки в умовах інтенсивного прояву гірського тиску.

Результати. Даний експеримент продемонстрував, що границі зруйнованого масиву розширюються асинхронно, прирощуючи зону руйнування окремими порціями у просторі й часі. Такий механізм розвитку зони зруйнованих порід $€$ наслідком закону про мінімум виробництва ентропії, який стверджує, що у відкритих термодинамічних системах можуть виникати дисипативні структури.

Наукова новизна. Дальня взаємодія породних кластерів у масиві гірських порід була експериментально зареєстрована вперше, що $є$ важливим у галузі геомеханіки, оскільки було підтверджено механізм самоорганізації масиву гірських порід.

Практична значимість. Найбільш ефективні спеціальні технології були виявлені й кількісно оцінені для управління станом масиву гірських порід в умовах інтенсивного прояву гірського тиску.

Ключові слова: гірський тиск, стійкість гірничої виробки, необоротні деформаиії, кластер, дальня взаємодія

\section{ABSTRACT (IN RUSSIAN)}

Цель. Экспериментально доказать наличие дальнего взаимодействия породных кластеров во время необратимых сдвижений массива горных пород. Дезинтеграция массива горных пород не обязательно влечет за собой потерю устойчивости подземной выработки. 
Методика. Используя глубинные реперы, осуществлен мониторинг массива горных пород вокруг подземной подготовительной выработки в условиях интенсивного проявления горного давления.

Результаты. Данный эксперимент продемонстрировал, что границы разрушенного массива расширяются асинхронно, приращивая зону разрушения отдельными порциями в пространстве и времени. Такой механизм развития зоны разрушенных пород является следствием закона о минимуме производства энтропии, который утверждает, что в открытых термодинамических системах могут возникать диссипативные структуры.

Научная новизна. Дальнее взаимодействие породных кластеров в массиве горных пород было экспериментально зарегистрировано впервые, что является важным в области геомеханики, поскольку было подтверждено механизм самоорганизации массива горных пород.

Практическая значимость. Наиболее эффективные специальные технологии были выявлены и количественно оценены для управления состоянием массива горных пород в условиях интенсивного проявления горного давления.

Ключевые слова: горное давление, устойчивость горной выработки, необратимье деформации, кластер, дальнее взаимодействие

\section{ARTICLE INFO}

Received: 10 February 2017

Accepted: 6 June 2017

Available online: 30 June 2017

\section{ABOUT AUTHORS}

Volodymyr Griniov, Doctor of Technical Sciences, Director of the Institute for Physics of Mining Processes of the National Academy of Sciences of Ukraine, 2a Simferopolska St, 49005, Dnipro, Ukraine. E-mail: grinovvv@ukr.net

Liudmyla Zakharova, Candidate of Technical Sciences, Doctorate of the Geodesy Department, Donetsk National Technical University, 2 Shybankova Sq, 85300, Pokrovsk, Ukraine. E-mail: zaharova mila1976@mail.ru

Ivan Diedich, Candidate of Technical Sciences, Manager of the MA "Pokrovske”, 1a Shybankova Sq, 85300, Pokrovsk, Ukraine. E-mail: dedichia@gmail.com

Victor Nazymko, Doctor of Technical Sciences, Senior Researcher of the Institute for Physics of Mining Processes of the National Academy of Sciences of Ukraine, 2a Simferopolska St, 49005, Dnipro, Ukraine. E-mail: victor.nazimko@gmail.com 